\title{
Correction: Is age a risk factor for cognitive changes following hematopoietic cell transplantation?
}

John Stratton (D) - Allison Sylvia • Flora Hoodin · Sung Won Choi (D) Attaphol Pawarode • Bruno Giordani • Kristen Votruba

Published online: 23 September 2020

(c) The Author(s), under exclusive licence to Springer Nature Limited 2020

Correction to: Bone Marrow Transplantation

https://doi.org/10.1038/s41409-020-01046-3

The original version of this Article contained an error in the second affilation. It was listed as "Department of
Neurology, University of Wisconsin-Madison, Madison, MI, USA". Madison is in the state of Wisconsin (WI) and not Michigan (MI). This has now been corrected in both the PDF and HTML versions of the Article. 